\title{
Anticipations of Hans Georg Gadamer’s Epistemology of History in Benedetto Croce's Philosophy of History
}

\author{
Cody Franchetti \\ Graduate School of Arts and Sciences, Columbia University, New York, USA \\ Email: history@codyfranchetti.com
}

Received January $3^{\text {rd }}, 2013$; revised February $5^{\text {th }}, 2013$; accepted February $18^{\text {th }}, 2013$

\begin{abstract}
Copyright () 2013 Cody Franchetti. This is an open access article distributed under the Creative Commons Attribution License, which permits unrestricted use, distribution, and reproduction in any medium, provided the original work is properly cited.
\end{abstract}

\begin{abstract}
In Truth and Method Hans Georg Gadamer revealed hermeneutics as one of the foundational epistemological elements of history, in contrast to scientific method, which, with empiricism, constitutes natural sciences' epistemology. This important step solved a number of long-standing arguments over the ontology of history, which had become increasingly bitter in the twentieth century. But perhaps Gadamer's most important contribution was that he annulled history's supposed inferiority to the natural sciences by showing that the knowledge it offers, though different in nature from science, is of equal import. By showing history's arrant independence from the natural sciences, the former was furnished with a newfound importance, and thrust on an equal footing with the latter-even in a distinctly scientific age such as ours. This essay intends to show that the idea of history's discrete ontology from science was prefigured almost a century earlier by Benedetto Croce. Croce and Gadamer show compelling points of contact in their philosophies, notwithstanding that they did not confer equal consequence to what may be identified as Gadamer's principal substantiation of history's epistemology-hermeneutics. Of course this essay does not aspire to be exhaustive: the thought of both philosophers is far too dense. Nevertheless, the main points of contact shall be outlined, and, though concise, this essay seeks to point out the striking similarities of these two cardinal philosophers of history.
\end{abstract}

Keywords: Gadamer; Croce; History; Epistemology of History; Historical Knowledge; Non-Scientific Truth; Hermeneutics; Tradition

\section{Introduction}

The history of the hermeneutic tradition and its application to history is essentially German. Born out of philology, which was dominated by Germany in the nineteenth century, the hermeneutic approach sought Truth in Interpretation. The first to embark into an ontology of hermeneutics was Friedrich Schleiermacher, who, in the first half of the nineteenth century, described the task and the nature of interpretation. If it was Schleiermacher who inaugurated modern hermeneutics, Hans Georg Gadamer brought its culmination, for in Truth and Method he revealed its original impetus-that of bearing truth outside of the natural sciences, which hitherto had its exclusive right. Applied historically, hermeneutics rid history of the shackling argument against its veracity_of being a "soft" science-and conferred its independence as an ulterior way of knowing. Gadamer demonstrated in its fullest sense that hermeneutic understanding is the epistemology of historical knowledge and how the latter is altogether different from scientific knowledge.

This conception of history was first held at the turn of the twentieth century by the Italian Benedetto Croce, who despite being situated well outside the European cultural dialogue-
Italy had become increasingly provincial in the nineteenth century-was one of the few Italian intellectuals who read and was influenced by Schleiermacher, and, more generally, by German philosophy. In history's gradual appropriation of its own, parascientific validity Benedetto Croce represents an important station, for his philosophy anticipates a number of Gadamer's concepts.

\section{The Demise of "Method" in History}

One of the most important aspects of Gadamer's thought has been the dismissal of the dominance of scientific method as the source of truth in historical understanding. This mental frame, Gadamer insists, is an inheritance of the natural science model inaugurated by Descartes. In his Idea of History, Collingwood recognized that it was Croce who for the first time posited history's independence from science:

Croce, by denying that history was a science at all, cut himself at one blow loose from naturalism, and set his face towards an idea of history as something radically different from nature. We have seen that the problem of philosophy everywhere in the late nineteenth century was the problem of liberating itself from 
the tyranny of natural science ${ }^{1}$.

It had taken a long time for the forces of skeptical positivism unleashed by the English and Scottish thinkers to weaken enough to conceive of another way of knowing; this other knowledge was not the one that originated with the reconstitution of the world outside Doubt. Croce's non-scientific interpretation of history superseded other similar, contemporary attempts such as Dilthey in Germany and Bergson in France: though both of them recognized the necessity of finding legitimacy outside of science, it was Croce's merit to separate history from natural science entirely.

Croce's argument toward an identity of history completely independent from empiricism was to unhinge it from the idea of "universal history". Universal history was an inheritance of German idealism; it was an ideal shared by the German historical school of the nineteenth century, which believed there was a history that existed in itself that was an objective act of selfconsciousness, part of a wider, collective consciousness. This was a manifestation of a concept that had originated in the Eighteenth century with Voltaire's Essai sur les Moeurs, but which fully sprouted in Germany with Hegel's concept of "Weltgeist"; its effects reverberated in historians" thought throughout the nineteenth century-often polemically. Ranke was a paradigmatic example, for he believed history to be composed of "spiritual beings" which in their totality would constitute "world history"; Droysen sought to understand the "inner essence" of things; Dilthey conceived of the historical world as an existing text that had to be deciphered. According to Gadamer, this idealistic footing was the limitation of nineteenth century's historiography: it had the positivist prejudice of an "infinite knowledge", as well as the belief in universal knowledge as a thing in itself; and despite the German historical school reacted to Hegel's eschatological vision of history as self-awareness, its stance nevertheless betrayed the age's epistemological prejudices:

The historical school was forced into a theological understanding of itself. If it was not to undermine its own disposition to think of itself as progressive research, it had to relate its own finite and limited knowledge to a divine spirit, to which things are known in their perfection. It is the old ideal of infinite understanding applied to the knowledge of history ${ }^{2}$.

Gadamer calls it the "old ideal", because despite nineteenthcentury historians and thinkers reacted to-or thought they were breaking off from - the rationality of the Enlightenment, they were still anchored to scientific models of knowing. Croce, too, violently opposed this old way of conceiving history, for he viewed the historical gaze as subjective. He refuted the notion of universal history by saying that "the only thing of importance is the actuality of the new situation and the new disposition of soul that has been produced" and that thus "we know at every moment all the history that we need to know; [...] That 'remaining' history is the eternal phantom of the 'thing itself', which is neither the 'thing' nor 'in itself', but only the imaginative projection of the infinity of our action and of our knowledge."3 Here, his polemic is mainly directed at Hegel's idealism that "taught reason in everything" that "to negate universal history does not mean to negate the

\footnotetext{
${ }^{1}$ Collingwood, 1946: p. 193.

${ }^{2}$ Gadamer, 2004: p. 207.

${ }^{3}$ Croce, 1923: p. 55.

${ }^{4}$ Gadamer, 2004: p. 216. Gadamer calls Hegel the last and most representa-

tive of ancient "logos" philosophy for this reason.
}

universal in history"5. This is the crux of his concept of history: the subjective thinker makes history by thinking it, and history is universal in its being thought. Therefore Collingwood's appellation of Croce's vision of what constitutes history-making as a methodology was mistaken: "within the concrete whole which is historical knowledge, philosophical knowledge is a component part: it is the thinking out of predicate-concepts. Croce put this by defining philosophy as the methodology of history." " Collingwood was fundamentally right in essence, but I would argue that his choice of the word "methodology" is misconceived since Croce inveighed against method in historical thinking.

\section{Narrative as an Escape from Science}

Croce's other argument for history's independence from science is the appropriation of the narrative element in history. Firstly, he stressed the distinction between history and chronicle. Chronicle, he maintained, is dead narrative-non-historical. History, on the other hand, while it may be composed of chronicle, is history only if thought out consciously.

First comes history, then chronicle: first comes the living being, then the corpse; and to make history the child of chronicle is the same thing as to make the living be born from the corpse, which is the residue of life, as chronicle is the residue of history ${ }^{7}$.

In other words, the act of narration must be performed to make sense of chronicles - to apply them to real life's continuum - and that very act is history. This idea is strikingly similar to Hayden White's; in fact, it is its direct antecedent. The only difference here between Croce and White is that the former considered chronicles themselves as being narratives, while White, under the influence of the postmodernist "linguistic turn", deemed the world—including chronicles—as a form of storytelling itself. Croce's modernity here should be stressed: thinkers of the later $20^{\text {th }}$ century such as Danto, Hayden-White, and Ricoeur, who have been hailed as great originals, did not duly acknowledge this contribution by Croce. After having distinguished with some insistence between chronicle and history, Croce makes the essential step of divesting historical knowledge from method when stating that the superiority of documents over narrative is a methodological prejudice that is entirely fictitious. "It was the clean cut which he made in 1893 between the idea of history and the idea of science that enabled him to develop the conception of history so much farther than any philosopher of his generation"8. It is of great historical interest to note that Croce himself did not recognize the significance and originality of his move, for he did not emphasize it: he spoke in an exalted state about connecting history to art but not about severing it from science. This, I believe, reveals a significant aspect of nineteenth-century culture: that Croce was not nearly as proud of severing history from science, as for having attached history to art, is symptomatic of a dominating current of the period, which believed that all eventually coalesces into art. It is also telling about our own time that Croce's abutment of art and history is disturbing today, for positivism, ironically, in the age of non-Newtonian physics, seems to have

\footnotetext{
${ }^{5}$ Croce, 1923: p. 59 .

${ }^{6}$ Collingwood, 1946: p. 201

${ }^{7}$ Croce, 1923: p. 20

${ }^{8}$ Collingwood, 1946: p. 193.
} 
regained its reins over the collective unconscious as the sole way of understanding 9 . And only those whom we consider radical thinkers recovered this idea in contemporary times, with statements like, say, "emplotment is the mimesis of action" (P. Ricoeur $)^{10}$.

\section{The Subjectivisation of History}

Let us now turn to some of the arguments made against Croce's and Gadamer's stance the "metaphysical" notion of history, another correspondence shall emerge. Somewhat similarly to Gadamer's reification of the historical immanence of an historian's prejudices, Croce posited history from the subjective point of view. In Historians and Historiography of the $19^{\text {th }}$ Century G. P. Gooch illuminates this aspect of Croce's philosophy:

The past, he [Croce] declares in History, its Theory and Practice, exists for us solely as a subjective idea of what happened. All history is contemporary history in the sense that we can only think of the past with the mind of our own day. The notion of sequence, indispensable for the practical purposes of life, fails to provide us with objective reality. The sole reality is subjective-occurred. History is not a science: unlike the world of nature, it has no ascertainable laws. Nor can any philosophic system be extracted from it, for every mind and every age regards it from a different angle. While the facts are historical, interpretations are purely subjective. To Croce the average historian is a mere chronicler, for facts only become history when they have passed through the crucible of an individual mind $^{11}$

Croce is in effect conferring authorship to the thinker of history. For this reason, it is not surprising that both Gadamer and Croce have been criticized as being relativistic; but the counter argument is already within their work, since the relativistic argument against them is mainly born out of oversimplification of their thought. Gadamer's description of understanding as an experience of history itself wrests the question of truth out of the reach of empiricism. For him, historical understanding is neither a child of method - or any normative datum — nor of relativism, because in our understanding of history our historicity is manifest: "In all understanding, whether we are aware of it or not, the efficacy of history is at work." ${ }^{12}$ Croce made a similar case when stating, "truth itself perishes, particular and

\footnotetext{
${ }^{9}$ I open, for example, a contemporary New York Times editorial and find the gray mentality that pervades today's rationality, as well as its general ignorance:

Some people live in romantic ages. They tend to believe that genius is the product of a divine spark. They believe that there have been, throughout the ages, certain paragons of greatness-Dante, Mozart, Einstein-whose talents far exceeded normal comprehension, who had an other-worldly access to transcendent truth, and who are best approached with reverential awe. We, of course, live in a scientific age, and modern research pierces hocuspocus. In the view that is now dominant, even Mozart's early abilities were not the product of some innate spiritual gift. His early compositions were nothing special. They were pastiches of other people's work. Mozart was a good musician at an early age, but he would not stand out among today's top child-performers. What Mozart had, we now believe, was the same thing Tiger Woods had-the ability to focus for long periods of time and a father intent on improving his skills. Mozart played a lot of piano at a very young age, so he got his 10,000 hours of practice in early and then he built from there (David Brooks, "Genius: the Modern View." The New York Times: 1 May 2009, A23).

${ }^{10}$ Ricoeur, 1990: p. 224.

${ }^{11}$ Gooch, 1959: p. xxxvi.

${ }^{12}$ Gadamer, 2004: p. 300.
}

determined truth, because it is not re-thinkable save when included in the system of a vaster truth and therefore at the same time transformed." ${ }^{13}$ Croce and Gadamer, in different ways, are expressing that truth is born out of interpretation, which is subjective, surely, but also based on the constantly changing truths of history (or the texts that the historian is trying to understand).

\section{Hermeneutics}

We have seen that Croce's subjectivisation of history prefigures Gadamer's ideas; but other antecedents of Gadamer's thought may be found in Croce's position in the history of the hermeneutic approach. Though Gadamer may be its culmination, we ought to start with Schleirmacher, for it was he who inaugurated modern hermeneutics and stressed the importance of reconstructing the meaning of the original intention of a text ${ }^{14}$. Schleiermacher was the first to speak of the hermeneutic circle; a metaphor for the way comprehension runs-understanding the part from the whole and the whole from the part. Since the movement from part to whole and back was constant, in a sort of gyrating motion, progressively expanding, he called it "Zirkel im Verstehen" or circle/compass of understanding/ comprehension. According to Schleiermacher, the hermeneutic circle was the methodology of understanding; and as a philologist he described the circle as the way we interpret texts. Croce was influenced by Schleiermacher's Aesthetic and wrote about it in a late essay ${ }^{15}$. In it Croce acknowledged Schleiermacher's foundational step for the independence of interpretation and language from logic, stating that "Schleiermacher circumscribed appropriately aesthetical understanding as a form of knowing that is not yet logical knowledge." ${ }^{16}$ Though Croce never wrote about hermeneutics directly, we may infer that he attached implicitly as much importance to it as Gadamer, since, as we saw, subjective understanding was to both thinkers the germ of historical thought. Croce's belief in the inalienable historicity of history-making is an earlier and less audacious step than Gadamer's concept that in understanding the past we bring ourselves into the historical situation; and with us we bring our own prejudices (or prejudgments) and as well as those of our age, which are history, even though some historians are still bound by the Cartesian "prejudice against prejudice" ${ }^{\text {"17 }}$ and beseech impartiality ${ }^{18}$.

Without explicitly mentioning the hermeneutic circle, Croce exhibited a Schleiermachean perspective of understanding: the part versus the whole and back, "The individual is called the subject of the judgment, the universal the predicate [...] But for him who dominates words with thought, the true subject of

\footnotetext{
${ }^{13}$ Croce, 1923: p. 91.

14“"To understand a writer better than he understood himself" is his famous and often quoted phrase.

${ }^{15}$ L'estetica di Schleiermacher, written in 1933.

${ }^{16}$ ["Schleiermacher bene circoscrisse il campo dell'Estetica come quello di un conoscere che non è ancora il conoscere logico.”] Croce, 1996: p. 554.

${ }^{17}$ Gadamer, 2004: p. 283.

${ }^{18}$ For the historian usually chooses concepts to describe the historical particularities of his objects without expressly reflecting on their origin and justification. He simply follows his interest in the material and takes no account of the fact that the descriptive concepts he chooses can be highly detrimental to his proper purpose if they assimilate what is historically different to what is familiar and thus, despite all impartiality, subordinate the alien being of the object to his own preconceptions. Thus, despite his scientific method, he behaves just like everyone else-as a child of his time who is unquestionably dominated by the concepts and prejudices of his own age. (Gadamer, 2004: p. 397).
} 
history is just the predicate, and the true predicate the subject." 19 Croce is following Schleiermacher closely-even literally, for Schleiermacher himself wrote, "The subject must receive its final determinacy via the predicate and the predicate via the subject"; Gadamer calls understanding a "fusion of horizons"; from this point of view, too, we may regard Croce as the link between Romantic hermeneutics and Gadamer, even though Croce did not address hermeneutics directly.

Other points of contact between Croce and Gadamer appear in their response to Dilthey's aporias. Dilthey was the first to apply hermeneutics as the epistemic tool of history. Gadamer acknowledged this contribution, but criticized Dilthey for envisaging historical understanding as a methodological practices, though hermeneutics and method are not commensurable (cfr. footnote 23):

Romantic hermeneutics and the philosophical method on which it is based are not adequate as the basis of historical study. Similarly, Dilthey's concept of inductive procedure, borrowed from the natural sciences, is inadequate [...] the epistemological Cartesianism that dominated him proved stronger, so that in Dilthey the historicity of historical experience is never truly integrated in his thought. [...] Thus Dilthey ultimately conceives inquiring into the past as deciphering and not as historical experience ${ }^{20}$.

Now Croce has, as far as I know ${ }^{21}$, only mentioned Dilthey once, in reference to Schleiermacher (polemically too, I might add, since he blamed him for not having heeded Schleiermacher's Aesthetic). But if we read Gadamer's last sentence above and confront it with Croce's quote below, Croce's anticipation of Gadamer's emphasis of history outside of empiricism-in flagrant opposition to Dilthey's epistemology-is evident:

[History] arouses the mind from its empirical slumbers and makes it see that in place of supposed things there are in reality spiritual acts [...] History would indeed be in a fix if it expected to be born of what comes after it, to be born of external things! Thing, not thought, is born of thing: a history derived from things would be a thing-that is to say, just the inexistent of which we were talking a moment ago ${ }^{22}$.

Croce's and Gadamer's proximity is evident here; both thinkers see the historical experience as a form of history. Croce's implication that history is an act of the spirit-a sort of phenomenology of the historian-fringes, albeit embryonically, with Heidegger's idea that understanding is ontological. It was upon Heidegger, who renewed previous questions of being (thus superseding Dilthey's aporias) that Gadamer built his recognition of the interpreter's prejudices as an essential constituent of historical understanding, since Heidegger showed that the latter is a function of the Dasein and its questions with temporality $^{23}$.

\footnotetext{
${ }^{19}$ Croce, 1923: p. 60.

${ }^{20}$ Gadamer, 2004: p. 234.

${ }^{21}$ In the 1681 pages of collected works of Croce's works on the philosophy history.

${ }^{22}$ Croce, 1923: p. 24.

${ }^{23}$ Gadamer studied with Heidegger in Freiburg in the mid 1920's and was influenced by him. According to Gadamer, Dilthey's limitations-in short, not having conceived of understanding itself as a historical act-were overcome by Heidegger. In Being and Time Heidegger designated the hermeneutic experience as the way we understand our being, our "thrown-ness" into the world. Heidegger saw interpretation as indissolubly tied with being, hence, not a method. Upon this conception of hermeneutics (as well as Heidegger's analysis of the historicity of the Dasein) Gadamer built his philosophy of historical understanding.
}

\section{Tradition}

Finally, Croce also anticipated Gadamer's stress on tradition. Croce found his own antecedent in the writings of Gianbattista Vico, who defined historical knowledge as different from the knowledge that the "modern sciences" yielded. According to Croce, Vico anticipated nineteenth-century philology by defining the influence of tradition over it: "[philology] proceeded by testing and selecting those authorities which seemed to it to be the most worthy of faith, it is always a question of faith and not of criticism, of verisimilitude and not that certainty that is truth." ${ }^{24}$ Gadamer, too, in a chapter devoted to Vico acknowledged the latter as a lonely voice in the struggle against methodological strictures, who instead appealed to tradition and sensus communis against the abstract universality of reason: "He does not deny the merits of modern critical science but shows its limits. Even with this new science and its mathematical methodology, we cannot do without the wisdom of the ancients and [...] the training in the sensus communis, which is not nourished on the true but the probable, the verisimilar."25 Here the correspondence between Gadamer and Croce is not only conceptual but also literal.

\section{Conclusion}

It is curious that Gadamer disregarded Croce despite the philosophical similarities of his Italian antecedent. That Gadamer praised Vico for his crucial role in the reaction against the preeminence of scientific knowledge over all other forms of knowledge makes Gadamer's disregard for Croce ever more conspicuous. After all, Vico influenced Croce more than any other thinker, and, as we have seen, Croce himself indubitably anticipated Gadamer's thought. Yet in Truth and Method Gadamer mentions Croce but once and does not acknowledge neither his contribution nor his landmark position; he mentions Croce only in passing — and unfavorably_in a passage where discussing Emilio Betti, an Italian legal historian who wrote on legal hermeneutics: "Clearly reacting against Croce's extreme position, Betti seeks the mean between the objective and the subjective element in all understanding."26 Gadamer here is displaying the same superficiality, as we saw above in the facile criticism that had been directed at Gadamer himself, when the latter was accused of relativism. Croce, as we saw above, in stating that "truth itself perishes [...] because it is not rethinkable save when included in the system of a vaster truth [...]" he affirmed that the 'subjective' truth a historian generates in his understanding of history is always set against "a vaster truth" which contravenes its possible excesses. This is exactly the same defense that Gadamer made when countering the portrayal of his thought as relativistic: Gadamer's saying that our being indissolubly rooted in history means we understand it by fusing our own truths with that of history - the very thing we are trying to understand-is strikingly similar to Croce's argument. The similarity of the criticism leveled against both Gadamer and Croce, as well as their defense, abuts these two philosophers considerably.

I should like to end this essay with a quote from Gadamer, which, while embracing Croce's fundamental-as well as historical-move of history outside the realm of natural science,

\footnotetext{
${ }^{24}$ Croce, 1923: p. 29.

${ }^{25}$ Gadamer, 2004: p. 19.

${ }^{26}$ Gadamer, 2004: p. 511.
} 


\section{FRANCHETTI}

also reveals the marrow of Gadamer's idea of historical understanding:

Anticipating an answer itself presupposes that the questioner is part of the tradition and regards himself as addressed by it. This is the truth of historically affected consciousness. It is the historically experienced consciousness that, by renouncing the chimera of perfect enlightenment, is open to the experience of history $^{27}$.

Gadamer, through an itinerary that started with Schleiermacher and passed through the ideas of Benedetto Croce has re-attached us to the original meaning of the word history, the one embodied in its etymological root "his" that itself stems from the Indo-European root "vid"- - view.

\section{REFERENCES}

Collingwood, R. G. (1946). The battered child (5th ed.). London: Oxford University Press.

Croce, B. (1923). History, its theory and practice. New York: Harcourt, Brace \& Co.

Croce, B. (1996). Filosofia, poesia, storia. Milano: Adelphi Edizioni. Gadamer, H. G. (2004). Truth and method. London: Continuum.

Gooch, G. P. (1959). History and historians in the nineteenth century. Boston, MA: Beacon Press.

Ricoeur, P. (1990). Time and narrative, volume 1. Chicago, IL: University of Chicago Press.

\footnotetext{
${ }^{27}$ Gadamer, 2004: p. 370.
} 